Politik Indonesia: Indonesian Political Science Review 2 (1) (2017) 46-64

Politik Indonesia

Indonesian Political Science Review

http://journal.unnes.ac.id/nju/index.php/JPI

\title{
Pembangunan Desa Berbasis Potensi Lokal Agrowisata di Desa Bumiaji, Kota Batu, Jawa Timur
}

Irma Fitriana Ulfah $^{1 凶}$, Andi Setiawan ${ }^{1}$, Alfiyatur Rahmawati ${ }^{1}$

${ }^{1}$ Universitas Brawijaya, Indonesia

\begin{tabular}{|c|c|}
\hline Info Artikel & Abstrak \\
\hline $\begin{array}{l}\text { Sejarah Artikel: } \\
\text { Diterima 10 Agustus } 2016 \\
\text { Disetujui } 20 \text { Desember } 2016 \\
\text { Dipublikasi } 15 \text { Januari } 2017\end{array}$ & $\begin{array}{l}\text { Pembangunan desa salah satunya dapat dilakukan dengan pengembangakan potensi } \\
\text { lokalnya. Desa Bumiaji merupakan desa agrowisata dengan berbagai potensi, mulai } \\
\text { dari wisata petik apel, jeruk, jambu kristal, wisata bunga, peternakan kambing etawa, } \\
\text { dan Usaha Mikro, Kecil dan Menengah (UMKM) hasil dari produksi agrowisata }\end{array}$ \\
\hline $\begin{array}{l}\text { Keywords: } \\
\text { Rural Development; } \\
\text { Sustainable Development; } \\
\text { Agrotourism }\end{array}$ & $\begin{array}{l}\text { Stoker yang mencakup } 3 \text { aspek yaitu aspek ekologi, sosial dan ekonomi. Hasil } \\
\text { penelitian menunjukkan bahwa proses pembangunan di Desa Bumiaji telah memenuhi } \\
\text { aspek-aspek dari pembangunan berkelanjutan, namun dalam prosesnya masih belum } \\
\text { bisa berjalan maksimal. Potensi agriowisata merupakan sumber daya utama dalam } \\
\text { melakukan pembangunan ekologis. Dari aspek keadilan sosial, potensi agrowisata } \\
\text { telah memberikan manfaat dan dampak kepada pemilik lahan, pemerintah desa dan } \\
\text { warga sekitar. Pembanguan ekonomi di Bumiaji bertumpu sumber daya alam yakni } \\
\text { produksi dari ladang dan sawah. Pembangunan agrowisata ini dapat meningkatkan } \\
\text { pendapatan masyarakat dan perluasan tenaga kerja, sehingga kesejahteraan warga bisa } \\
\text { meningkat. Pembangunan desa berbasis potensi lokal agrowisata perlu terus } \\
\text { dikembangkan. Hal ini dapat dilakukan melalui pengembangan SDM, promosi dan } \\
\text { peningkatan sarana dan prasarana. }\end{array}$ \\
\hline
\end{tabular}

\section{Abstract}

Rural development one of them to do with the development of local potential. Bumiaji village is a village with a variety of potential agrotourism, ranging from travel picking apples, oranges, pink crystals, flower travel, etawa breeding, and Micro, Small and Medium Enterprises result from the production of agro stretcher. This study examined the theory of sustainable development according to Von Stoker which includes three aspects: ecological, social and economic. The results showed that the process of development in the village Bumiaji has fulfilled the aspects of sustainable development, but in the process is still not able to walk up. Agriowisata potential is the main resource in conducting ecological development. From the social aspect, the potential for ecotourism has provided benefits and impacts to the land owner, the village government and local residents. Bumiaji economic development relies on natural resources and the production of paddy fields. This agro-tourism development can increase people's income and the expansion of the labor force, so that the welfare of the citizens can be increased. Rural development based on local potential agrotourism should be developed. This can be done through human resource development, promotion and improvement of facilities and infrastructure.

(C) 2017 Universitas Negeri Semarar

\footnotetext{
Alamat korespondensi:

Gedung Darsono Lt 2 Fakultas Ilmu Sosial dan Ilmu Politik, Universitas Brawijaya, Malang, Indonesia

Email: irmafittt@gmail.com
}

ISSN $2477-8060$ 


\section{Pendahuluan}

Berdasarkan Undang-Undang No. 23 Tahun 2014 Tentang Pemerintahan Daerah Bab II pasal 2 disebutkan bahwa daerah kabupaten/kota dibagi atas kecamatan dan kecamatan dibagi atas kelurahan dan/atau desa. Selain itu, desa telah mempunyai payung tersendiri yang secara spesifik mengatur tentang desa, yang ditandai dengan lahirnya UU Desa No. 6 tahun 2014 tentang desa. Selain adanya UU Desa juga telah dibentuk Kementerian Desa, PDT dan Transmigrasi, yang dapat memberikan semangat baru dalam mendukung desa agar lebih mandiri dan inovatif. Berdasarkan UU No. 6 tahun 2014 tentang Desa, bahwa:

"Desa adalah desa dan desa adat atau yang disebut dengan nama lain, selanjutnya disebut Desa, adalah kesatuan masyarakat hukum yang memiliki batas wilayah yang berwenang untuk mengatur dan mengurus urusan pemerintahan, kepentingan masyarakat setempat berdasarkan prakarsa masyarakat, hak asal usul, dan/atau hak tradisional yang diakui dan dihormati dalam sistem pemerintahan Negara Kesatuan Republik Indonesia".

Berdasarkan definisi di atas menunjukkan bahwa desa dapat menjalankan otonominya sendiri yaitu menjalankan pemerintahannya berdasarkan hak asal usul dan adat istiadatnya, atau yang dapat disebut dengan otonomi asli. Selain pengaturan tentang otonomi desa, UU desa juga menjelaskan tentang kewenangan desa yang salah satunya adalah kewenangan dalam bidang pembangunan desa. Kewenangan pembangunan desa ini termuat dalam UU No.

6 tahun 2014 Bab IV pasal 18 bahwa:

"Kewenangan dibidang
penyelenggaraan pemerintahan desa,
pelaksanaan pembangunan desa,
pembinaan kemasyarakatan desa,
dan pemberdayaan masyarakat desa
berdasarkan prakarsa masyarakat,
hak asal usul, dan adat istiadat
desa".

Lebih lanjut lagi dijelaskan bahwa kewenangan desa meliputi: Pertama, Kewenangan berdasarkan hak asal usul. Menurut Didik Sukrino (2010) kewenangan asal usul desa mencakup pengelolaan asset desa, seperti pengelolaan sumber daya alam. Dengan adanya kewenangan ini maka desa dapat melakukan pembangunan desanya sesuai dengan potensi yang ada. Kedua, kewenangan lokal berskala Desa. Ketiga, kewenangan yang ditugaskan oleh Pemerintah, Pemerintah Daerah Provinsi, atau Pemerintah Daerah Kabupaten/Kota. Keempat, kewenangan lain yang ditugaskan oleh Pemerintah, Pemerintah Daerah Provinsi, atau Pemerintah Daerah Kabupaten/Kota sesuai dengan ketentuan peraturan perundangundangan.

Sesuai Undang-Undang No. 6 Tahun 2014 Tentang Desa pasal 78 poin (1) menjelaskan bahwa potensi ekonomi lokal desa menjadi syarat adanya pembangunan desa yang bertujuan meningkatkan kesejahteraan masyarakat desa dan kualitas hidup manusia. Pembangunan desa yang 
sesuai dengan potensi dan sumber daya lokal yang dimiliki dapat dijadikan sebagai icon bagi desa tersebut. Oleh karena itu, pembangunan potensi unggulan yang dimiliki oleh suatu desa dapat berbeda dengan desa yang lain. Hal ini dikarenakan setiap desa memiliki keanekaragaman yang khas, baik dari sisi ekonomi, sosial, budaya dan geografis. Berdasarkan UU No. 6 tahun 2014 tentang Desa Bab I Pasal I, bahwa "Pembangunan Desa adalah upaya peningkatan kualitas hidup dan kehidupan untuk sebesar-besarnya kesejahteraan masyarakat desa." Pentingnya upaya untuk mendukung pembangunan desa ditindaklanjuti dengan dikeluarkannya Peraturan Menteri Dalam Negeri Republik Indonesia Nomor 114 Tahun 2015 Tentang Pedoman Pembangunan Desa. Berdasarkan Peraturan Menteri tersebut bahwa pembangunan desa dilakukan oleh Pemerintah Desa yang didukung adanya partisipasi masyarakat desa dengan semangat gotong royong.

Kota Batu merupakan salah satu kota di Jawa Timur yang merupakan hasil pemekaran dari Kabupaten Malang. Peresmian Kota Batu ini pada tanggal 17 Oktober 2001. Kota Batu terdiri dari 3 kecamatan, 20 desa dan 4 kelurahan. Kota Batu merupakan kota pariwisata dengan city branding "Shinning Batu". Oleh Bappenas, Kota Batu dijuluki sebagai "The real tourism city of Indonesia" (http://ciptakarya.pu.go.id).
Grafik 1. Pusat Lingkungan di Bagian Wilayah Kota Batu

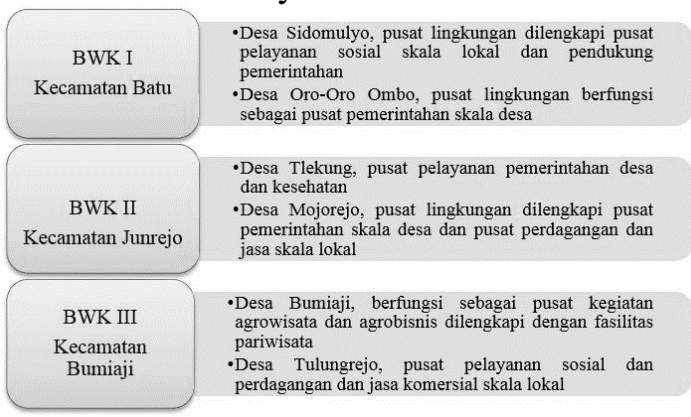

Sumber: Peraturan Daerah tentang RTRW Kota Batu Tahun 2010-2030.

Berdasarkan Perda No. 7 tahun 2011 RTRW Kota Batu Tahun 2010-2030, bahwa Kota Batu dibagi menjadi 3 bagian wilayah kota (BWK). BWK I berada di Kecamatan Batu merupakan wilayah utama pengembangan pusat pemerintahan kota. BWK II berada di Kecamatan Junrejo yang merupakan wilayah utama pengembangan pemukiman kota dan dilengkapi dengan pusat pelayanan pemerintahan. BWK III berada di Kecamatan Bumiaji yang menjadi wilayah utama pengembangan kawasan agropolitan, wisata alam dan lingkungan.

Penetapan Kecamatan Bumiaji sebagai pengembangan kawasan agrowisata berdasarkan pada luas wilayah Kecamatan Bumiaji sebesar 12.798,42 Ha atau 64\% dari total luas Kota Batu yaitu 19.908,72 Ha. Sudah sesuai dengan kebijakan yang ada bahwa Kecamatan Bumiaji memang dikhususkan sebagai pusat agrowisata dan agrobisnis. Kecamatan Batu lebih untuk kawasan perkotaan sedangkan Kecamatan Junrejo tanahnya tidak sesubur di Bumiaji. 
Desa Agrowisata Bumiaji yang berada di Kecamatan Bumiaji merupakan gagasan untuk mewujudkan pembangunan yang berbasis pertanian yang bersinergi dengan dunia pariwisata. Potensi yang ada di Desa Bumiaji tersebar dalam 4 dusun, yakni Dusun Beru, Binangun, Banaran, dan Tlogorejo. Potensi yang dikembangkan terdiri dari wisata petik jambu kristal, wisata petik jeruk, wisata petik apel, wisata bunga krisan dan mawar, peternakan susu kambing etawa, serta hasil pengolahan agrowisata yakni dalam bidang UMKM.

Pembangunan potensi lokal berbasis agrowisata memberikan dampak positif bagi petani, masyarakat desa, dan pemerintah desa. Akan tetapi di sisi lain karena pembangunan potensi ini mengandalkan SDA, pengembangannya juga sangat tergantung dengan alam. Anomali cuaca yang sulit diprediksi, hujan tidak menentu menyebabkan budidaya buah-buahan semakin sulit dan produksinya semakin menurun. Selain itu, terbatasnya anggaran dan peran pemerintah desa untuk menciptakan program-program unggulan dalam mendukung pengembangan potensi lokal berbasis agrowisata.

Pembangunan Desa Bumiaji dalam mengembangkan potensi agrowisata menjadi tanggung jawab bersama antara pemerintah dan masyarakat. Dengan potensi yang dimiliki oleh Desa Bumiaji dalam sektor agrowisata akan sangat membantu dalam meningkatkan perekonomian masyarakat desa tersebut. Melalui sektor agrowisata, Pemerintah Desa berupaya untuk mencapai tujuan tersebut dengan melibatkan masyarakat untuk bersama-sama mengambil inisiatif pembangunan desa, karena di samping sebagai potensi lokal atau wilayah, peranan dan kesadaran masyarakat dalam pembangunan desa didorong dan ditumbuhkan agar hasilnya dapat dinikmati oleh seluruh lapisan masyarakat.

\section{Kajian Pustaka}

\section{Pembangunan Berkelanjutan}

Paradigma pembangunan yang terjadi di Indonesia pada abad ke 21 ini mengalami pergeseran salah satunya menuju pembangunan berkelanjutan. Pembangunan berkelanjutan umumnya didefinisikan sebagai pembangunan yang dapat memenuhi kebutuhan saat ini tanpa menghilangkan kemampuan generasi yang akan datang untuk memenuhi kebutuhan mereka. Untuk tercapainya pembangunan berkelanjutan, diperlukan tiga syarat, yaitu terlanjutkan secara ekologi, ekonomi dan sosial. Kegagalan pembangunan dapat terjadi apabila salah satu syarat tidak terpenuhi. Dengan demikian, pembangunan berkelanjutan dapat diartikan sebagai upaya meningkatkan kualitas hidup secara berkelanjutan (Asdak, 2012).

Pembangunan berkelanjutan mencakup 3 aspek penting yakni ekologi, ekonomi dan sosial (Asdak, 2012). Lebih lanjut dijelaskan oleh Sumarwoto dalam Sugandhy dan Hakim (2007), bahwa: 
"Pembangunan berkelanjutan adalah perubahan positif sosial ekonomi yang tidak mengabaikan sistem ekologi dan sosial di mana masyarat bergantung kepadanya. Keberhasilan penerapannya memerlukan kebijakan, perencanaan, dan proses pembelajaran sosial yang terpadu viabilitas politiknya tergantung pada dukungan penuh masyarakat melalui pemerintahannya, kelembagaan sosialnya dan kegiatan dunia usaha."

Von Stoker menjelaskan adanya 3 pilar pembangunan berkelanjutan yakni perlunya koordinasi dan integrasi sumber daya alam, sumber daya manusia, dan sumber daya buatan dalam setiap pembangunan nasional, dengan pendekatan kependudukan, pembangunan dan lingkungan sampai dengan integrasi aspek sosial, ekonomi, dan lingkungan. Skema pembangunan berkelanjutan Von Stoker dapat dilihat pada gambar di bawah ini:

Gambar 1. Skema Pembangunan Berkelanjutan (Sustainable Development)

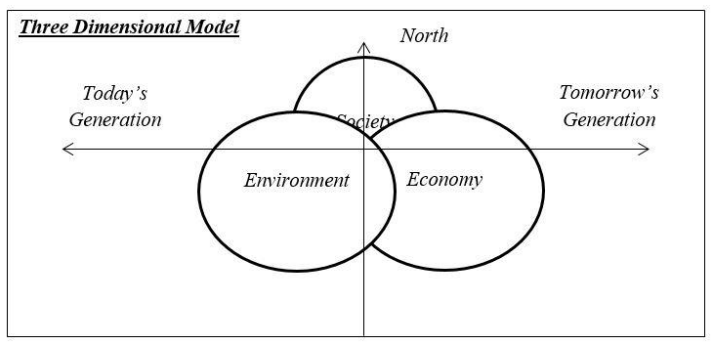

Sumber: Von Stoker dalam Sugandhy dan Hakim (2007).

Pembangunan berkelanjutan Von Stoker mencakup 3 aspek, antara lain: Pertama, keberlanjutan sistem sosial. Menurut aspek ini bahwa sumber daya alam harus dimanfaatkan dengan memerhatikan aspek pemerataan dan keadilan sosial bagi para pemangku kepentingan. Keberlanjutan sistem sosial menekankan pada peningkatan kualitas dari pada kuantitas. Partisipasi masyarakat menjadi salah satu kunci keberlanjutan sistem sosial ini.

Kedua, keberlanjutan ekonomi. Keberlanjutan ekonomi dimaknai cara untuk "mempertahankan" atau menjaga kapital (sumber daya alam, sumber daya manusia, sumber daya buatan, dan sumber daya sosial) agar tidak mengalami kemerosotan. Ketiga, keberlanjutan ekologis. Keberlanjutan ekologi sangat diperlukan oleh kehidupan manusia karena kehidupan manusia ditentukan oleh keberadaan dan kualitas lingkungan. Untuk sumber daya alam yang tidak dapat diperbaharui, sebagian keuntungan yang diperoleh dari pemanfaatan sumber daya alam tersebut seharusnya digunakan untuk menciptakan (inovasi) teknologi, sehingga dapat menciptakan bentuk kegiatan ekonomis. Dengan demikian, aktivitas sosial, ekonomi, dan didukung dengan kemampuan ekologi akan berkelanjutan mengiringi laju pembangunan.

Tidak hanya masyarakat yang memiliki peran kuat dalam pembangunan, pemerintah dengan seluruh jajaran aparatnya tetap memainkan peranan yang sangat penting dalam pembangunan. Menurut Munir (2010) dalam bukunya Konsep Negara Demokrasi, peran pemerintah sesuai dengan fungsinya antara lain: pertama, Enterpreneur. Pemerintah bertanggungjawab untuk melaksanakan usaha dalam mengelola sumber daya ekonomi, mengelola aset-aset sumber 
daya ekonomi potensial, sehingga secara ekonomi menguntungkan dan memberi manfaat bagi masyarakat. Kedua, Koordinator. Sebagai koordinator pemerintah dapat menetapkan kebijaksanaan atau strategi bagi pembangunan dan merangkul semua komponen masyarakat untuk menjadi aktor dalam pembangunan. Ketiga, Fasilitator. Sebagai fasilitator pemerintah dapat mempercepat pembangunan melalui perbaikan lingkungan attitudional, yaitu berkaitan dengan perbaikan prosedur perijinan dan pelayanan, serta melakukan penetapan untuk memantapkan pengaturan dimensi spasial dalam pembangunan.

\section{A. Pengembangan Agrowisata}

Agrowisata atau agrotourism di Indonesia merupakan sebuah bentuk kegiatan pariwisata yang memanfaatkan usaha agro (agrobisnis) sebagai objek wisata (http://eprints.undip.ac.id). Pengembangan agrowisata berbasis potensi lokal dapat memberikan dampak positif bagi warga masyarakat, pemerintah dan juga pihak swasta. Upaya pengembangan agrowisata secara garis besar mencakup 5 aspek (http://database.deptan.go.id), antara lain:

Pertama, sumber daya manusia (SDM). SDM berperan penting dalam pengembangan agrowisata. Tidak hanya ketersediaan pemandu wisata tetapi juga pengetahuan dan keterampilan pemandu terkait produk wisata.

Kedua, promosi dapat dilakukan melalui berbagai cara, seperti leaflet, booklet, pameran, cinderamata, mass media (dalam bentuk iklan atau media audiovisual), serta penyediaan informasi di tempat publik (hotel, bandara, restoran, dll). Selain itu, promosi juga dapat dilakukan dengan cara melakukan kerjasama dengan biro/agen perjalanan dan perhotelan. Ketiga, sumber daya alam dan lingkungan. Usaha agrowisata sangat tergantung pada alam, sehingga keberlanjutannya tergantung bagaimana upaya untuk mempertahankan kelestarian dan keasrian sumber daya alam dan lingkungan.

Keempat, dukungan sarana dan prasarana. Aksesibilitas untuk menjangkau lokasi agrowisata menjadi hal yang tidak bisa diremehkan. Kemudahan akomodasi dan transportasi sangat mendukung pengembangan usaha agrowisata. Serta kemudahan dalam pemberian pelayanan kepada pengunjung/wisatawan juga menjadi aspek penting dalam keberhasilan pengembangan agrowisata. Kelima, kelembagaan. Pengembangan agrowisata perlu peran dari berbagai stakeholder, baik itu dari pemerintah, masyarakat, atau pihak swasta. Pemerintah bertindak sebagai fasilitator dalam mendukung berkembangnya agrowisata dalam bentuk kemudahan pengaturan agar tidak terjadi iklim usaha yang saling mematikan. Untuk itu kerjasama baik antara pengusaha objek agrowisata, maupun antara objek agrowisata dengan lembaga pendukung (perjalanan wisata, perhotelan dan lainnya) sangat penting. 


\section{Metodologi}

Penelitian ini menggunakan jenis penelitian kualitatif. Penelitian kualitatif diartikan sebagai jenis penelitian yang temuan-temuanya tidak diperoleh melalui prosedur statistik atau bentuk hitungan lainnya (Strauss dan Corbin, 2013). Jenis penelitian kualitatif desktiptif ini untuk mendeskripsikan temuan- temuan menarik terkait pembangunan desa berbasis potensi lokal agrowisata yang ada di Desa Bumiaji Kecamatan Bumiaji Kota Batu.

Creswell menjelaskan teknik pengumpulan data kualitatif dapat dilakukan melaui wawancara, observasi atau pengamatan, dan dokumentasi (Creswell, 2014). Menurut Moleong wawancara adalah percakapan yang dilakukan antara dua pihak yaitu pewawancara yang mengajukan pertanyaan dengan terwawancara yang memberikan jawaban (Moleong, 2012). Wawancara merupakan pengumpulan data utama dengan melakukan tanya jawab kepada narasumber tentang pembangunan desa berbasis potensi lokal agrowisata. Wawancara yang digunakan dalam penelitian ini adalah wawancara tidak terstruktur, yang bisa secara leluasa melacak ke berbagai segi dan arah guna mendapatkan informasi yang selengkap mungkin dan semendalam mungkin. Dengan begitu, upaya understanding of understanding bisa terpenuhi secara memadai (Moleong, 2007).

Selain wawancara, teknik pengumpulan data juga dilakukan melalui observasi atau pengamatan. Observasi dilakukan dengan mengamati bagaimana proses pembangunan desa yang berbasis potensi lokal agrowisata. Observasi dapat dilakukan oleh peneliti dengan secara langsung ikut terlibat dalam proses yang sedang dialami subjek penelitian. Dalam hal ini peneliti tidak boleh terlihat sangat menonjol dan mengganggu situasi di lapangan yang sedang berlangsung. Jadi pada intinya pada observasi tersebut, secara tidak langsung peneliti menjadi bagian dari kegiatan yang sedang berlangsung di lapangan. Pengamatan yang dilakukan oleh peneliti menyesuaikan dengan obyek penelitian dan berlandaskan teori dan pengetahuan yang dimiliki oleh peneliti.

Tidak kalah penting juga pengumpulan berbagai dokumen-dokumen dari lokasi penelitian dan studi pustaka. Beberapa dokumen yang didapatkan antara lain: Rancangan Pembangunan Jangka Menengah Desa (RPJMDes) Bumiaji Tahun 2015-2021, Rancangan Peraturan Desa Bumiaji (Raperdes) tentang Penetapan Desa Bumiaji sebagai Desa Wisata, Surat Keputusan Kepala Desa Bumiaji tentang Pengesahan Pengangkatan Anggota Pengurus Kelembagaan Wisata Bukit Apel Desa Wisata Bumiaji, Data Kelompok Tani Bumiaji, Data Strategis Desa Bumiaji, Data Kerjasama Kelembagaan, Rancangan Penggunaan Dana ADD Bumiaji Tahun 2012 dan 2014, Data Potensi Desa Bumiaji Tahun 2016, LPJ 
PNPM Pariwisata Desa Bumiaji Tahun 2010 serta Peta Potensi Desa Bumiaji.

Pada tahap selanjutnya, peneliti berusaha untuk menganalisis data-data yang sudah dikumpulkan dengan menggunakan langkah-langkah yang sesuai dengan metode penelitian yang dilakukan. Peneliti dalam hal ini mengikuti metode analisis data Huberman dan Miles yang terdiri dari tiga hal utama, yaitu: (1) reduksi data; (2) penyajian data; dan (3) penarikan kesimpulan/verifikasi.

\section{Temuan dan Diskusi}

Desa Bumiaji merupakan salah satu desa di Kecamatan Bumiaji Kota Batu. Desa Bumiaji terbagi menjadi 4 Dusun, yaitu Dusun Banaran terdiri dari 5 RW dan 19 RT, Dusun Beru terdiri dari 2 RW dan 4 RT, Dusun Binangun terdiri dari $3 \mathrm{RW}$ dan $12 \mathrm{RT}$ dan Dusun Tlogorejo terdiri dari 2 RW dan 4 RT. Dari segi jarak Desa dengan pusat pemerintahan, jarak dengan Kecamatan Bumiaji 3 Km, jarak dengan Kota Batu 3 Km. Jumlah penduduk Desa Bumiaji adalah 6.197 jiwa, dimana mayoritas penduduknya bekerja sebagai petani.

Jumlah penduduk Desa Bumiaji adalah 6.197 jiwa, yang terdiri dari jumlah penduduk berjenis kelamin laki-laki sebanyak 3.092 jiwa dan penduduk berjenis kelamin perempuan sebanyak 3.105 jiwa. Dari keseluruhan jumlah penduduk Desa Bumiaji, mayoritas penduduk bermatapencaharian sebagai petani. Secara detail mata pencaharian penduduk Desa Bumiaji dapat dilihat pada tabel berikut:

Tabel 1. Varian Mata Pencaharian Masyarakat Desa Bumiaji

\begin{tabular}{|c|l|c|}
\hline No. & \multicolumn{1}{|c|}{ Pekerjaan } & Jumlah (orang) \\
\hline 1. & Petani & 1.654 \\
\hline 2. & Pelajar/Mahasiswa & 1.366 \\
\hline 3. & Ibu Rumah Tangga & 974 \\
\hline 4. & Pedagang & 506 \\
\hline 5. & Pegawai Swasta & 523 \\
\hline 6. & Pensiunan & 52 \\
\hline 7. & Guru/Dosen & 52 \\
\hline 8. & Industri/Wiraswasta & 45 \\
\hline 9. & TNI & 23 \\
\hline 10. & Dokter & 6 \\
\hline 11. & $\begin{array}{l}\text { Buruh Tani/Buruh } \\
\text { Harian Lepas }\end{array}$ & 425 \\
\hline 12. & $\begin{array}{l}\text { Bidan/Tenaga } \\
\text { Medis Lain }\end{array}$ & 89 \\
\hline 13. & Pegawai Negeri & 461 \\
\hline 14. & $\begin{array}{l}\text { Belum Kerja/Tidak } \\
\text { Bekerja }\end{array}$ & $\mathbf{6 . 1 9 7}$ \\
\hline 15. & Lainnya & Total \\
\hline
\end{tabular}

Sumber: RPJM Desa Bumiaji (2016).

Pertanian merupakan basis utama pembangunan di Desa Bumiaji. Beberapa jenis tanaman yang dibudidayakan adalah tanaman buah (apel, jeruk, jambu) dan tanaman hortikultura (bawang merah, bawang putih, tomat, seledri, brokoli, kol, cabe, kubis dan sawi-sawian) dan tanaman pangan (padi, jagung, ketela pohon, ubi jalar) dan juga mulai mengembangkan dan membudidayakan Tanaman Rosella dan tanaman jenis toga.

Selain komoditas pertanian, sebagian penduduk juga bekerja dan mengembangkan sektor industri kecil antara lain pembuatan jenang apel, sari apel dan kripik buah-buahan dan pembuatan macam-macam kripik lainnya. Selain itu, pembuatan mebeler, pembuatan 
sandal juga dikembangkan oleh sebagian warga masyarakat Desa Bumiaji.

Hal yang mulai dikembangkan di Desa Bumiaji sebagai salah satu usaha untuk mendongkrak perekonomian masyarakat antara lain adalah usaha pengembangan sektor pariwisata dengan usaha pengembangan wisata petik apel yang lebih dikenal dengan nama Wisata Bukit Apel Desa Bumiaji. Sedangkan untuk mendukung usaha peningkatan hasil usaha di bidang pertanian dan usaha penyelematan lingkungan masingmasing dusun yang ada di Desa Bumiaji dibentuk kelompok tani dan kelompok ternak sesuai dengan usaha masing-masing yang ada di dalam kelompok masyarakat. Berbagai macam potensi ekonomi yang ada di Bumiaji pun juga menyebar di 4 (empat) dusun secara merata.

Tabel 2. Fasilitas Sarana dan Prasarana Ekonomi

\begin{tabular}{|c|l|l|}
\hline No. & Potensi Ekonomi & \multicolumn{1}{|c|}{ Lokasi Dusun } \\
\hline 1. & Kerajinan Batik & Beru \\
\hline 2. & $\begin{array}{l}\text { Pengolahan Kunyit } \\
\text { dan Jahe }\end{array}$ & Binangun, Beru \\
\hline 3. & Produk Tradisional & Beru \\
\hline 4. & Konveksi & Beru \\
\hline 5. & $\begin{array}{l}\text { Jenang dan Dodol } \\
\text { Apel }\end{array}$ & $\begin{array}{l}\text { Binangun, Beru, } \\
\text { Banaran }\end{array}$ \\
\hline 6. & Keripik Kentang & Banaran \\
\hline 7. & Keripik Buah & Banaran \\
\hline 8. & $\begin{array}{l}\text { Minuman Sari } \\
\text { Buah }\end{array}$ & $\begin{array}{l}\text { Tlogorejo, } \\
\text { Binangun, } \\
\text { Banaran } \\
\text { Binangun }\end{array}$ \\
\hline 9. & Souvenir dan & Binangun \\
\hline 10. & $\begin{array}{l}\text { Percetakan } \\
\text { Sablon }\end{array}$ & $\begin{array}{l}\text { Binangun, } \\
\text { Banaran }\end{array}$ \\
\hline 11. & Kerajinan dan Topi \\
\hline 12. & $\begin{array}{l}\text { Jajanan Oleh-Oleh } \\
\text { Batu }\end{array}$ & Beru \\
\hline
\end{tabular}

Sumber: RPJM Desa Bumiaji (2016).

Pembangunan desa yang berbasis potensi lokal dapat dianalisis dengan memadukan 3 aspek penting yaitu keberlanjutan ekologis, ekonomi, dan sosial. Masing-masing dari ketiga aspek ini dijelaskan sebagai berikut:

\section{Aspek Ekologis}

Keberlanjutan ekologis sangat diperlukan karena keberlanjutan kehidupan manusia ditentukan oleh keberadaan dan kualitas lingkungan. Desa Bumiaji merupakan salah satu desa yang cukup kaya dengan sumber daya alamnya. Sebagian besar warga Desa Bumiaji berprofesi sebagai petani, oleh karenanya tidak heran jika sebagian besar lahan di Desa Bumiaji merupakan tegal/ladang dan sawah. Secara detail peruntukan lahan di Bumiaji dapat dilihat pada tabel di bawah ini:

Tabel 3. Peruntukan Lahan Desa Bumiaji

\begin{tabular}{|c|l|r|}
\hline No. & \multicolumn{1}{|c|}{ Wilayah } & $\begin{array}{c}\text { Luas } \\
\text { Wilayah }\end{array}$ \\
\hline 1. & Sawah irigasi teknis & 70 ha \\
\hline 2. & Sawah irigasi semi teknis & 27 ha \\
\hline 3. & Tegal/ladang & 212 ha \\
\hline 4 & Permukiman umum & 43,2 ha \\
\hline 5 & Permukiman real estate & 1.5 ha \\
\hline 6 & Tanah kas desa & 33,08 ha \\
\hline 7 & Lapangan & 2,3 ha \\
\hline 8 & Perkantoran & 1,3 ha \\
\hline 9 & Jalan & 28,6 ha \\
\hline
\end{tabular}

Sumber: RPJM Desa Bumiaji (2016).

Desa Bumiaji mempunyai beberapa potensi unggulan, terutama produk buahnya. Pada tahun 2016 produk unggulannya yakni apel dan jeruk keprok. Produksi buah-buahan di Desa Bumiaji secara detail dapat dilihat pada tabel berikut: 
Tabel 4. Jumlah Produksi dan Produktivitas Tanaman Tahunan di Desa Bumiaji Tahun 2016

\begin{tabular}{|c|l|c|c|c|c|}
\hline & & & & \\
\hline
\end{tabular}

Potensi Desa Bumiaji” (2016).

Pemerintah Kota Batu saat ini telah mendorong desa-desa yang masuk dalam wilayah utama pengembangan kawasan agropolitan, wisata alam dan lingkungan untuk menggunakan pertanian organik. Di Desa Bumiaji sendiri masih menggunakan pertanian semi organik yakni perpaduan antara penggunaan bahan kimia dengan bahan alami. Demi mendukung keberlanjutan ekologis, Desa Bumiaji mempunyai program menanam pohon pada setiap awal musim hujan. Untuk mewujudkan program ini dibentuk sebuah kelompok tani. Peran dari kelompok tani, masyarakat, pemerintah desa dan Dinas Kehutanan dan Lingkungan Hidup Kota Batu pada tahun 2010 berhasil melakukan penanaman 2000 pohon jenis mahoni, suren, dan tanaman buah-buahan.

Lembaga Pemberdayaan Masyarakat Desa (LPMD) juga berperan dalam penanaman pohon di kanan kiri jalan desa. Serta peran dari pihak swasta yakni USAID yang melakukan program pembibitan dan penanaman pohon di sekitar lahan pertanian. Keberlanjutan ekologis di Desa Bumiaji sangat dijaga yakni dengan tetap mempertahankan adanya lahan hijau. Seperti yang disampaikan oleh Rakhmad Hardianto selaku pengelola wisata petik Jambu Kristal (2016) bahwa upaya pelestarian lingkungan salah satunya dengan berkomitmen agar pembagian wilayah Desa Bumiaji berupa 5\% bangunan dan $95 \%$ tanaman. Pembangunan rest area atau homestay sebagai pendukung agrowisata di Bumiaji dibangun di luar lahan agrowisata.

Selain penanaman pohon, upaya yang dilakukan untuk menjaga keberlanjutan ekologis adalah dengan mengadakan kerja bakti. Kerja bakti biasanya dilakukan secara kondisional untuk menjaga kebersihan lingkungan. Kebijakan membuang sampah pada tempatnya juga dilakukan untuk mendorong keberlanjutan ekologi, serta didukung dengan penyediaan tempat sampah khususnya di sekitar tempat wisata.

Seluruh potensi yang ada di Desa Bumiaji secara detail dapat dilihat pada peta berikut ini: 
Gambar 2. Peta Potensi Desa Bumiaji

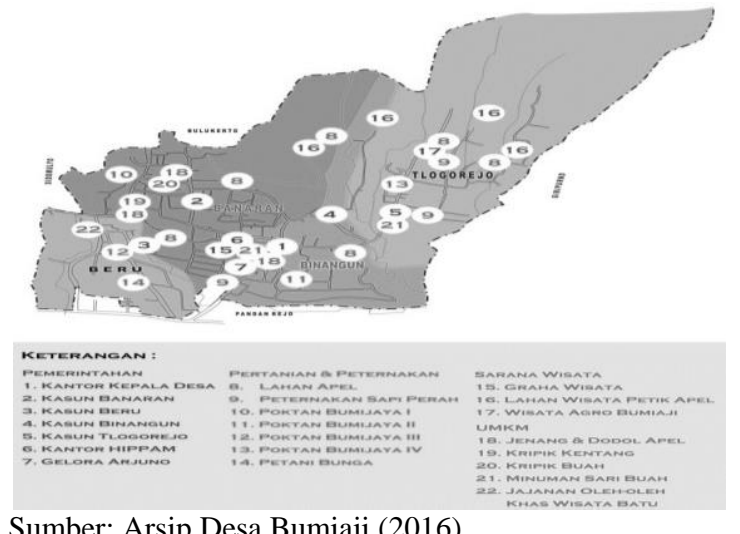

Sumber: Arsip Desa Bumiaji (2016).

\section{Aspek Keadilan Sosial}

Aspek keadilan sosial ini meliputi 5

hal, antara lain: pertama, pemerataan dan keadilan sosial. Potensi agrowisata di Desa Bumiaji dimiliki oleh perseorangan, akan tetapi menfaatnya dapat dirasakan oleh banyak pihak. Tidak hanya oleh masyarakat pemilik lahan, tetapi juga warga sekitar dan pemerintah desa. Seperti yang disampaikan oleh Kepala Desa Bumiaji:

"Dampak yang dirasakan sudah merata tidak terbatas hanya warga yang mempunyai lahan, tetapi juga warga lokal Bumiaji yang mempunyai sarana pendukung transportasi, warga-warga yang berjualan di sekitar tempat wisata, tukang parker, tidak terkecualipara karang taruna Desa Bumiaji sendiri yang menjadi pemandu wisata (guide) paling tidak sudah merasakan manfaar dengan adanya potensi agrowisata di Desa Bumiaji” (Edy Suyanto: 2016).

Pemanfaatan hasil dari potensi agrowisata misalnya dari hasil tiket masuk wisatawan dibagi secara merata antara petani/pemilik lahan, pemerintah desa, dan biro wisata. Harga tiket masuk ke agrowisata
Desa Bumiaji sebesar Rp. 17.500,00/orang. Pembagiannnya adalah Rp. 10.000,00 untuk hasil petani sampai jika ada kerusakan lahan akibat ulah wisatawan semua tercover dari nominal tersebut. Pemerintah desa mendapatkan Rp. 5.000,00 sebagai kegiatan operasional desa, sedangkan pelaku wisata mendapat Rp. 2.500,00.

Keuntungan pemerintah desa yang masuk dalam Pendapatan Asli Desa (PADes) sebesar Rp. 1.000.000,00/tahun. Nominal tersebut masih tergolong kecil, karena kelompok agrowisata di Desa Bumiaji masih dalam tahap pengembangan secara mandiri. Potensi agrowisata jangan hanya dilihat dari nominal yang didapatkan oleh pemerintah desa, akan tetapi adanya agrowisata ini sudah mampu membuka banyak lapangan pekerjaan. Beberapa lapangan pekerjaan yang terbentuk setelah adanya agrowisata adalah petani pemilik lahan, buruh petani, pelaku wisata, usaha home stay, jasa transprostasi, Industri Mikro, Kecil, dan Menengah (UMKM), dan masyarakat lokal yang berprofesi sebagai pemilik warung, toko, dan tukang parkir.

Tabel 5. Harga Tiket Masuk Potensi Agrowisata Desa Bumiaji

\begin{tabular}{|c|c|}
\hline $\begin{array}{c}\text { Nama } \\
\text { Kunjungan } \\
\text { Agrowisata }\end{array}$ & $\begin{array}{l}\text { HTM/Harga } \\
\text { Beli/Produksi }\end{array}$ \\
\hline Wisata Petik Apel & Rp. 17.500,-/orang \\
\hline $\begin{array}{l}\text { Wisata } \quad \text { Petik } \\
\text { Jeruk }\end{array}$ & $\begin{array}{l}\text { Rp. 12.500,-/orang dan Rp. } \\
\text { 15.000,-/orang }\end{array}$ \\
\hline $\begin{array}{l}\text { Wisata Petik } \\
\text { Jambu Kristal }\end{array}$ & Rp. 15.000,-/orang \\
\hline $\begin{array}{l}\text { Wisata } \quad \text { Petik } \\
\text { Bunga }\end{array}$ & Rp. 10.000,-/orang \\
\hline $\begin{array}{l}\text { Wisata Edukasi } \\
\text { Kambing Etawa }\end{array}$ & Rp. 20.000,-/liter susu \\
\hline Wisata Industri & Olahan jenang\&dodol \\
\hline
\end{tabular}




\begin{tabular}{|l|l|}
\hline $\begin{array}{l}\text { Rumah Tangga } \\
(\text { UMKM) }\end{array}$ & $\begin{array}{l}31.680 \mathrm{Pcs} / \mathrm{Bln} \\
\text { Olahan keripik buah } \pm \\
3.700 \mathrm{Kg} / \mathrm{Bln}\end{array}$ \\
& $\begin{array}{l}\text { Pia apel \& nangka } \pm 3.300 \\
\text { Pcs/Bln }\end{array}$ \\
\hline
\end{tabular}

Sumber: Arsip Pelaku Wisata Desa Bumiaji (2016).

Kedua, peningkatan kualitas dan kuantitas. Hal ini dilakukan dengan melakukan diversifikasi dari fokus pada potensi apel, sekarang berkembang pada potensi jeruk, jambu Kristal, petik bunga potong maupun bunga hias, peternakan kambing etawa, dan berkembangnya home industry pengolahan hasil agrowisata tersebut. Selain dari sisi kuantitas, pengembangan kualitas juga dilakukan seperti dalam pemberian pelayanan kepada pengunjung. Seperti yang disampaikan oleh pengelola wisata petik jambu kristal bahwa:

"Adanya sistem yang dibangun dalam memberikan pelayanan. Ketika tamu datang, dilakukan briefing terlebih dahulu, diperkenalkan tentang pertanian berbasis wisata, dibangun rasa kedekatan terhadap alam, baru kemudian melakukan wisata petik buah, makan dan pulang (Rakhmad Hardianto, 2016).”

Ketiga, partisipasi masyarakat. Kepala desa dan masyarakat sepakat untuk membuat suatu kelompok yang awalnya bernama Wisata Bukit Apel (WBA) pada tahun 2004. Kelompok ini mengalami perubahan nama menjadi kelompok Desa Wisata Bumiaji pada tahun 2012. Setelah baru berkembang adanya kelompok Sadar Wisata (Pokdarwis) yang merupakan kepanjangan tangan dari Pemerintah Kota Batu. Dari sisi partisipasi masyarakat masih ada masyarakat yang bersikap apatis terhadap pembangunan agrowisata di Desa Bumiaji.

Keempat, peningkatan pelayanan publik. Pelayanan publik dilakukan oleh pemerintah desa dengan cara memberikan keterbukaan informasi. Misalnya ketika ada pendanaan dari pemerintah kota kemudian disosialisasikan kepada warga desa. Begitu juga kalau warga membutuhkan pendanaan, maka pemerintah desa bisa membantu memfasilitasi dan koordinasi ke SKPD terkait di Pemerintah Kota Batu seperti dengan Bappeda, Dinas Pertanian, dan Dinas pariwisata (Wiwit, 2016). Keterbukaan informasi yang dilakukan pemerintah desa yakni dengan mengadakan musyawarah desa yang mengundang berbagai stakeholder terkait rencana dan penggunaan Alokasi Dana Desa (ADD).

Kelima, peningkatan kualitas SDM. Pembangunan agrowisata di Desa Bumiaji mengedepankan kultur budaya yang dijunjung tinggi oleh masyarakat lokal. Hal ini dilakukan dengan penamaan-penamaan tata kelola agrowisata. Misalnya home stay disebut dengan pakerman. Welcome drink dinamakan unjukan panunggal artinya minuman nomor satu. Tour guide pria disebut sebagai sinoman dan tour guide wanita disebut sebagai bioto. Peningkatan kualitas SDM juga dilakukan melalui pelatihanpelatihan seperti pelatihan tentang tour guide profesional, penataan home stay, dan 
pelatihan tentang pengembangan jiwa kewirausahaan.

Pembangunan agrowisata ini melibatkan berbagai stakeholder mulai dari pelaku wisata dan kelompok tani, pemerintah desa dan juga swasta. Pelaku wisata dan kelompok tani merupakan pelaku utama dalam pembangunan agrowisata. Hal ini dilakukan dalam membuka lapangan pekerjaan, menaikkan pendapatan masyarakat serta berperan dalam mendukung jumlah pengunjung atau wisatawan ke agrowisata Bumiaji. Beberapa kelompok yang berperan penting dalam pembangunan agrowisata ini adalah Kelompok Sadar Wisata (Pokdarwis), Gabungan Kelompok Tani (Gapoktan), dan Wisata Bukit Apek (WBA).

Pokdarwis merupakan kelompok bentukan dari Pemerintah Kota Batu yang ada di semua desa di Kota Batu. Akan tetapi kedudukan Pokdarwis di tingkat desa sendiri masih belum jelas, sehingga kinerjanya juga dirasa kurang maksimal. Berbeda dengan Pokdarwis, kelompok tani di Bumiaji dinilai lebih aktif dalam pengembangan agrowisata. Di Desa Bumiaji ada 1 Gapoktan yakni Gapoktan Bumijaya Abadi yang diketuai oleh Bapak M.Chamim. selain itu, ada 12 kelompok tani di Desa Bumiaji, yang secara detail daftar nama kelompok tani di Desa Bumiaji dapat dilihat pada tabel berikut:

Tabel 6. Kelompok Tani

\begin{tabular}{|c|l|c|c|c|}
\hline No. & \multirow{2}{*}{$\begin{array}{c}\text { Nama } \\
\text { Kelompok } \\
\text { Tani }\end{array}$} & Ketua & Sekretaris & Bendahara \\
\cline { 3 - 5 } & Bumiaji I & Imam W & Yukron & M. Chamim \\
\hline 2. & $\begin{array}{l}\text { Bumijaya } \\
\text { II }\end{array}$ & Supriadi & $\begin{array}{c}\text { Muji } \\
\text { Teguh }\end{array}$ & Darmanto \\
\hline 3. & Bumijaya & M. Yusuf & Yoyok & Mathadi \\
\hline
\end{tabular}

\begin{tabular}{|c|l|c|c|c|}
\hline & III & & Fachrudin & \\
\hline 4. & $\begin{array}{l}\text { Bumijaya } \\
\text { IV }\end{array}$ & Andrianto & Yusuf & Winardi \\
\hline 5. & Abimanyu & $\begin{array}{c}\text { Agus } \\
\text { Kurniawan }\end{array}$ & Dani & Widi Asmoro \\
\hline 6. & Ajijaya & Sulianto & Ajib & Tarmat \\
\hline 7. & $\begin{array}{l}\text { Tirto } \\
\text { Makmur }\end{array}$ & Usma & Kusnu & Misdi \\
\hline 8. & Akal & Imam Gojali & Indriono & Ridwan \\
\hline 9. & $\begin{array}{l}\text { Bumi } \\
\text { Rahayu }\end{array}$ & Suhartini & Li'anah & \\
\hline 10. & $\begin{array}{l}\text { Citra } \\
\text { Lestari }\end{array}$ & Ningrowati & Riati & Nasri'ah \\
\hline 11. & $\begin{array}{l}\text { Wanita } \\
\text { Amanah }\end{array}$ & Sulianah & Winarti & Susiati \\
\hline 12. & $\begin{array}{l}\text { Bumi } \\
\text { Abadi }\end{array}$ & Widi & \multicolumn{2}{|c|}{} \\
\hline
\end{tabular}

Sumber: Arsip Petugas Penyuluh Lapangan "Data

Potensi Desa Bumiaji” (2016).

Selain Pokdarwis dan Gapoktan, juga adanya Wisata Bukit Apel (WBA). WBA mulai berdiri sejak akhir tahun 2005 dan diresmikan pada bulan Juli 2006 oleh Walikota Batu, pada saat yang bersamaan Desa Bumiaji dicanangkan sebagai desa wisata. WBA merupakan suatu organisasi atau lembaga yang berbentuk paguyuban atau asosiasi, dibawahi secara langsung oleh Kepala desa dan masuk ke dalam pemerintahan desa. Organisasi ini bukan lembaga yang berorientasi profit penuh, karena organisasi ini juga berorientasi kepada pembangunan masyarakat (sosial). Kepengurusannya terdiri dari seluruh unsur masyarakat Bumiaji.

Berkaitan dengan kepengurusan, struktur kepengurusan WBA di Desa Bumiaji juga belum tertata. WBA masih berjalan hingga sekarang meskipun namanya berubah menjadi kelompok Wisata Desa Bumiaji. Ketiga aktor perwakilan dari masyarakat lokal Bumiaji bisa dikatakan sebagai aktor utama dalam pelaksanaan pembangunan agrowisata, hal ini dikarenakan memang prioritas Desa Bumiaji untuk mengedepankan pemberdayaan 
masyarakat. Masyarakat khususnya pelaku wisata dan kelompok tani yang menentukan sendiri arah keberhasilan dari pembangunan agrowisata itu sendiri namun tidak terlepas dari koordinasi dengan Pemdes Bumiaji.

Pemerintah Desa Bumiaji dalam pembangunan agrowisata ini dapat berlaku sebagai fasilitator, koordinator dan juga regulator. Dukungan Pemerintah Desa dalam pembangunan agrowisata ini dibuktikan melalui visi misi kepala desa terpilih periode 2015-2021 yaitu:

"Misi: Terwujudnya Desa Bumiaji sebagai Desa Agrowisata yang religious, berpemerintahan kreatif, inivatif, mengutamakan pelayanan prima, dan bermasyarakat sejahtera lahir dan batin. Misi: Mewujudkan Bumiaji Sebagai Desa Agrowisata yang Religius Berpemerintahan kreatif, inovatif, mengutamakan pelayanan prima dan bermasyarakatan Sejahtera Lahir dan Batin. Dari visi misi kepala desa tersebut, salah penekanannya adalah dalam pembangunan agrowisata yang diturunkan ke dalam beberapa indikator yaitu menciptakan sistem pertanian yang maju dan mandiri serta ramah lingkungan, mengembangkan industri pertanian yang berbasis masyarakat dan keunggulan lokal, dan mewujudkan sapta pesona wisata yang bernuansa kearifan lokal."

Melalui visi misi kepala desa jelas memberikan bukti bahwa Pemerintah Desa telah berkomitmen untuk terlibat dalam pembangunan desa yang berbasis agrowisata. Pemerintah desa juga memberikan fasilitas basecame yakni graha wisata yang dapat dijadikan sebagai sarana berkumpul para pelaku wisata. Sebagai regulator Pemerintah Desa terlibat dalam pembuatan kebijakan desa tentang kepengurusan wisata bukit apel yakni Surat Keputusan Kepala Desa Bumiaji Nomor 141/13/KEP/422.330.330.5/2009 tentang Pengesahan Pengangkatan Anggota Pengurus Kelembagaan Wisat Bukit Apel Desa Wisata Bumiaji.

Pihak swasta juga memberikan kontribusi penting dalam pengembangan agrowisata di Desa Bumiaji. Sektor swasta yang ada di Bumiaji yakni Apple Sun Learning Center. Apple Sun merupakan learning center pertama yang ada di Kota Batu. Apple Sun Learning Center merupakan salah satu sub unit dalam keluarga besar Kaliwatu Group di Kota Wisata Batu. Tujuan dibangunnya Apple Sun Learning Center adalah sebagai tempat pelatihan bagi perusahaan dan sekolah untuk membangun mental, attitude, teamwork, entrepreneur, leadership dan pengembangan karakter. Bentuk kerjasama yang dijalin Desa Bumiaji dengan sektor swasta yakni Apple Sun hanya sebatas penyambung tamu yang datang ke apple sun jika ingin berwisata petik baik itu petik apel, jeruk, jambu maupun bunga maka pihak apple sun akan membawa pengunjung ke potensi agrowisata Bumiaji sesuai keinginan tamu yang bersangkutan. Tidak hanya wisata petik, jika tamu ingin membeli oleh-oleh yang lengkap dengan sistem edukasi pengolahan hasil agrowisata maka tamu bisa diarahkan ke potensi home industry Desa 
Bumiaji. Hal ini tentu saja akan menambah kuantitas tamu yang datang ke potensi-potensi agrowisata Desa Bumiaji.

\section{Aspek Ekonomi}

Aspek ekonomi merupakan aspek terakhir dalam pilar pembangunan berkelanjutan. Kapital yakni sumber daya alam merupakan aspek penentu dalam pembangunan agrowisata berbasis pertanian. Mayoritas mata pencaharian di Desa Bumiaji adalah petani dengan lahan milik perorangan. Dengan lahan yang ada mereka tanami buah, sayur, dan bunga yang dimanfaatkan untuk kegiatan agrowisata.

Sumberdaya alam yang berupa lahan tersebut merupakan aspek vital dalam keberhasilan pembangunan agrowisata, para pemilik lahan menjaga dan mengolah secara maksimal lahan yang mereka punya agar manfaat yang didapatkan pun juga banyak. Ketika apel mengalami penurunan produktivitas, petani mulai berinovasi yakni melakukan diversivikasi tanaman. Tidak hanya fokus pada tanaman apel tetapi mulai mengembangkan buah yang lain yang bernilai tinggi seperti buah jambu kristal dan jeruk. Meskipun pada akhirnya petani memproduksi buah juga bergantung dengan kondisi alam yang tidak ditentukan oleh manusia (Wiwit, 2016).

Potensi agrowisata yang dikembangkan di Desa Bumiaji memberikan dampak pada peningkatan pendapatan masyarakat dan perluasan tenaga kerja.
Pengembangan potensi lokal sebagai upaya untuk memerangi kemiskinan pedesaan sehingga kesejahteraan warga bisa meningkat. Pemerintah Desa Bumiaji yang salah satunya berwenang dalam pembangunan desa dibuktikan dengan mengalokasikan dana pada pengembangan potensi agrowisata. Dana yang dialokasikan ini berasal dari dana ADD yakni pada tahun 2012 sebesar Rp. 2.500.000,00 yang digunakan untuk penambahan fasilitas Graha Wisata sebagai basecame kegiatan agrowisata. Pada tahun 2014 ada alokasi yang diberikan untuk operasional Pokdarwis sebesar Rp. 1.000.000,00. Artinya dukungan anggaran dari pemerintah desa digunakan untuk belanja operasional, dibandingkan dengan pembangunan dan pemberdayaan masyarakat. Jadi, meskipun kepala desa telah berkomitmen melalui visi misinya, akan tetapi tidak ditindaklanjuti dalam dukungan anggaran.

Jika dilihat dari jumlah nominal bisa dikatakan dana dari Pemerintah Desa masih minim. Akan tetapi di sisi lain pemerintah desa membantu memberikan fasilitas pertanian dan peternakan seperti bantuan bibit jeruk kepada kelompok tani, bantuan pupuk organik kepada kelompok tani apel, bantuan ternak kambing, bantuan mesin pencacah rumput, bantuan mesin pellet, bantuan tong pakan, dan bantuan alat produksi apel. Hal ini sesuai data yang dihimpun dari LKPJ Kepala Desa Bumiaji Tahun 2012.

Dalam bidang perindustrian dan perdagangan yang ada yaitu UMKM, untuk 
menggairahkan usaha industri rumah tangga, Pemdes melalui LPMD memberikan bantuan beruapa penambahan modal bagi pelaku industri. Dana diperoleh dari $\mathrm{ADD} / \mathrm{K}$ tahun 2012 Program Ekonomi Produktif. Di samping itu bagi pelaku industri yang sudah berjalan dengan baik (mempunyai modal, pemasaran lancar), Pemdes berusaha untuk mengajukan bantuan berupa peralatan yang menunjang proses produksi.

\section{Pengembangan Agrowisata}

Pengembangan agrowisata di Desa Bumiaji dilakukan melalui berbagai aspek, antara lain: Pertama, pengembangan sumber Daya Manusia (SDM). Pengembangan SDM dilakukan melalui berbagai pelatihan, yang lebih banyak diinisiasi oleh pelaku wisata. Sedangkan pemerintah desa memberikan fasilitas berupa penyediaan tempatnya. Salah satu pelatihan yang pernah dilakukan adalah pelatihan menjadi guide professional, pelatihan tentang penataan homestay, dan pelatihan tentang jiwa kewirausahaan dengan mendatangkan pemilik produk Baboon T-Shirt dan Direktur CV Bintang Bersinar Malang. Meskipun pelatihan jarang dilakukan, akan tetapi hal ini tidak menjadi kendala. Jika ada tamu yang datang dalam jumlah banyak, pelaku wisata dapat melibatkan karang taruna. Karang taruna ini sudah tergabung dalam HPI (Himpunan Pramuwisata Indonesia) dan BGC (Batu Guide Community), dimana latar belakang mereka memang sudah dilatih dan mempunyai bekal dalam bidang pariwisata sesuai dengan standar pariwisata.

Kedua, promosi merupakan kunci dalam mendorong kegiatan agrowisata. Informasi dan pesan promosi dapat dilakukan melalui berbagai cara,seperti melalui leaflet, booklet, pameran, cinderamata, mass media (dalam bentuk iklan atau media audiovisual), serta penyediaan informasi pada tempat publik (hotel, restoran, bandara dan lainnya). Promosi dilakukan secara langsung dan tidak langsung. Promosi secara langsung dilakukan dengan cara mulut ke mulut (word of mouth). Promosi wisata dengan cara ini merupakan promosi yang paling murah dan bisa dikatakan cukup efektif karena adanya keterlibatan langsung dalam berinteraksi sehingga orang lebih mudah percaya dengan cerita yang didengarkan dari pengunjung sebelumnya berdasarkan pengalaman saat datang ke lokasi wisata yang dikunjunginya.

Promosi secara tidak langsung biasanya dilakukan melalui media cetak maupun media sosial. Yang dimaksud dengan media cetak atau display diantaranya yaitu dengan membuat brosur atau selebaran terkait dengan potensi agrowisata. Brosur ini biasanya dibagikan kepada pengunjung agrowisata, juga pernah dibagikan dalam kegiatan Jatim Fair saat Desa Bumiaji mengikuti pameran Jatim Fair tersebut. Potensi-potensi agrowisata Desa Bumiaji juga pernah dimuat dalam Koran Jawa Pos pada 24 Februari 2015, dalam koran tersebut disebutkan beberapa obyek wisata di Desa 
Bumiaji lengkap dengan harga tiket masuk serta keadaan desa agrowisata Bumiaji sampai pada saat ini. Selain pembuatan brosur dan berita di koran, promosi secara tidak langsung juga dilakukan melalui media sosial seperti facebook, twitter dan youtube. Promosi melalui media sosial tidak menghabiskan biaya yang mahal tetapi mempunyai dampak yang besar mengingat di jaman globalisasi seperti sekarang ini internet merupakan media yang tidak asing lagi bagi masyarakat luas dan sifatnya sangat mudah diakses.

Ketiga, dukungan sarana dan prasarana. Dukungan sarana dan prasarana yang dibuat dalam pembangunan agrowisata Desa Bumiaji ini tidak berlebihan, sesuai dengan social culture yang ada di pedesaan. Apabila tamu yang datang dalam jumlah besar membawa beberapa bus, tempat parkir disediakan di basecamp graha wisata yang memang tempatnya cukup luas. Di Bumiaji sendiri masjid juga banyak untuk tempat beribadah bagi tamu muslim. Bagi tamu yang menginap, disediakan homestay. Ada sekitar 50 rumah yang dijadikan homestay di Dusun Beru, satu rumah dapat ditempati oleh 6 sampai 7 orang. Tarif yang ditetapkan sesuai dengan fasilitas kisaran Rp. 20.000/orang/malam. Fasilitas selayaknya di pedesaan yaitu tempat untuk tidur, toilet dengan tambahan makan yang bersifat kondisional sesuai permintaan wisatawan.

Dalam menunjang kegiatan agrowisata, diperlukan juga prasarana transportasi sebagai pelengkap sarana yang sudah ada sehingga dapat membawa wisatawan untuk berkunjung ke tujuan wisata mereka. Transportasi yang dimaksud adalah sepeda motor maupun mobil dari masyarakat lokal Bumiaji. Karena jarak antar lokasi agrowisata di Bumiaji tidak jauh, maka cukup menggunakan motor atau mobil warga yang bisa digunakan sehingga memudahkan wisatawan untuk sampai ke lokasi wisata yang diinginkannya. Khusus untuk wisata petik apel yang letaknya agak jauh dari pusat Desa Bumiaji yaitu berada di Dusun Tlogorejo, biasanya wisatawan memanfaatkan angkutan umum (mikrolet) untuk sampai di lokasi wisata petik apel.

\section{Kesimpulan}

Pembangunan potensi lokal di Desa Bumaji yang berbasis agrowisata telah memenuhi 3 aspek dalam pembangunan berkelanjutan. Pertama, aspek ekologis. Aspek ekologis menunjukkan bahwa sebagai desa wisata, Desa Bumiaji menjaga kelestarian sumber daya alam yang ada. Karena potensi utamanya berbasis agriowsisata, maka penjagaan lahan menjadi prioritas utama. Hal ini dibuktikan bahwa penggunaan terbesar di Desa Bumiaji tetap diperuntukkan untuk ladang dan sawah. Pengembangan kawasan agropolitan, wisata alam dan lingkungan juga dilakukan dengan adanya pertanian organik. Perawatan lingkungan dilakukan melalui kegiatan kerja bakti, akan tetapi sampai saat ini masih bersifat kondisional dan tidak ada jadwal 
rutin. Serta perlunya kesadaran seluruh elemen agar tidak membuang sampah sembarangan.

Kedua, aspek keadilan sosial. Potensi agrowisata di Desa Bumiaji dimiliki oleh perseorangan, akan tetapi menfaatnya dapat dirasakan oleh banyak pihak. Tidak hanya oleh masyarakat pemilik lahan, tetapi juga warga sekitar dan pemerintah desa. Aspek keadilan dilakukan dengan meningkatkan kualitas dan kuantitas potensi lokal, peningkatan pelayanan kepada pengunjung, partisipasi dan penguatan kelembagaan pihak yang terkait dalam pengelolaan agrowisata. Masyarakat lokal yang tidak terlibat dalam pengelolaan agrowisata sampai saat ini belum ada konntribusi yang signifikan.

Ketiga, aspek ekonomi. Kapital yakni ladang dan sawah merupakan sumber utama keberhasilan agrowisata. Oleh karena itu, tidak aneh jika mayoritas mata pencaharian di Desa Bumiaji adalah petani. Capital yang ada memberikan hasil berupa buah, sayur, dan bunga yang dimanfaatkan untuk kegiatan agrowisata. Dampak dari agrowisata ini dapat meningkatkan pendapatan masyarakat dan perluasan tenaga kerja, sehingga kesejahteraan warga bisa meningkat.

Penelitian ini selain membahas tentang pembangunan desa juga memberikan kajian tentan pengembangan agrowisata di Desa Bumiaji yang telah dilakukan melalui berbagai aspek, antara lain: pertama, melalui pengembangan Sumber Daya Manusia (SDM) khususnya pelaku wisata. Pemerintah desa
Bumiaji hanya melaksanakan peran coordinator dan fasilitator. Sedangkan peran entrepreneur justru lebih banyak dilakukan oleh masyarakat lokal khususnya pemilik potensi agrowisata. Kedua, promosi baik dilakukan secara langsung atau tidak langsung. Ketiga, adanya dukungan sarana dan prasarana.

\section{Daftar Pustaka}

Asdak, C. (2012). Kajian lingkungan hidup strategis: jalan menuju pembangunan berkelanjutan. Gadjah Mada University Press.

Creswell, J. W. (2014). Penelitian Kualitatif \& Desain Riset 3/E-: Memilih di Antara Lima Pendekatan.

Fuady, M., \& Gunarsa, A. (2010). Konsep negara demokrasi. Refika Aditama.

http://ciptakarya.pu.go.id/profil/profil/barat/jat $\mathrm{im} /$ batu.pdf.

http://eprints.undip.ac.id.

http://portal.batukota.go.id/berita-737-3-desadinobatkan-terbaik.html.

http://shining-batu.com/desa-wisatabumiaji.html.

Moleong, L. J. 2007. Metodologi penelitian kualitatif, 4-10.

Peraturan Pemerintah RI No. 12 Tahun 1993 tentang Pembentukan Kota Administratif Batu Bab IV mengenai Penataan Wilayah.

Permendagri No. 114 Tahun 2014 Tentang Pedoman Pembangunan Desa. 
Perda No. 7 tahun 2011 RTRW Kota Batu Tahun 2010-2030.

Sugandhy, A., \& Hakim, R. (2007). Prinsip dasar kebijakan pembangunan berkelanjutan berwawasan lingkungan. Bumi Aksara.

Strauss, A., \& Corbin, J. (2003). Dasar-dasar penelitian kualitatif. Yogyakarta: Pustaka Pelajar.

Undang-Undang Republik Indonesia No. 6 Tahun 2014 Tentang Desa.

Wawancara dengan Edy Suyanto, Kepala Desa Bumiaji, pada 11 Januari 2016.

Wawancara dengan Wiwit S, Kaur Pemerintahan Desa Bumiaji, pada 11 Februari 2016.

Wawancara dengan Rakhmad Hardianto, Pengelola Wisata Petik Jambu Kristal, pada 18 Februari 2016. 